\title{
Conversos, Moriscos, and the Eucharist in Early Modern Spain: Some Reflections on Jewish Exceptionalism
}

\author{
YONATAN GLAZER-EYTAN \\ Magdalene College, Cambridge University, Cambridge, UK \\ E-mail:yg382@cam.ac.uk
}

Accepted: 14 July 2021 / Published online: 3 December 2021

\begin{abstract}
Sacrilegious attitudes toward the Eucharistic host are one of the most commonplace accusations leveled against Jews in premodern Europe. Usually treated in Jewish historiography as an expression of anti-Judaism or antisemitism, they are considered a hallmark of Jewish powerlessness and persecution. In medieval and early modern Spain, however, Jews and conversos (Jewish converts to Christianity and their descendants) were not the only proclaimed enemies of the Eucharist. Reports about avoidance, rejection, criticism, and even ridicule and profanation of the consecrated host were similarly leveled against Muslims and moriscos (Muslim converts to Christianity). This essay seeks to assess the parallels and connections between the two groups through a comparative examination of accusations of sacrilegious behavior towards the host. The first part of the essay analyzes religious art, legal compendia, and inquisitorial trials records from the tribunals of Toledo and Cuenca in order to show some evident homologies between the two groups. The second part of the essay focuses on the analysis of the works of Jaime Bleda and Pedro Aznar y Cardona, two apologists of the expulsion of the moriscos, and draws direct connections between Jewish and morisco sacrilege. By exploring the similarities and differences between accusations against conversos and moriscos, this essay aims to offer a broader reflection on Jewish exceptionalism.
\end{abstract}

Keywords Iberian Jews · Conversos · Iberian Muslims · Moriscos · Christian-Jewish relations · Christian-Muslim relations · Eucharistic miracles · Inquisition · Jewish historiography

In 1597, a miracle occurred in the Spanish city of Alcalá de Henares. According to several seventeenth-century chapbooks, it all began when a band of New Christians who were wandering through Castile stole from local churches monstrances (custodias) that contained Eucharistic hosts. Being "people with no faith," as the accounts described the band of thieves, they disparaged the consecrated wafers and threw them on the ground. ${ }^{1}$ One of the bandits, the only one described as an "Old Christian," repented and returned a number of hosts to a local priest. The priest in turn consulted his

\footnotetext{
${ }^{1}$ See, for instance, Relación breve, y verdadera del milagro de las sagradas formas, que estan, y se ven en el colegio de la Compañia de Iesus de Alcala de Henares; Y testimonio que del dio el ilustrissimo señor D. Francisco de Mendoza, obispo, y gouernador del arçobispado de Toledo (Alcalá de Henares, 1634), fol. 1a, Biblioteca Nacional de España, VE/181/38.
} 
superior, who warned him that "such wicked people" were prone to poison Old Christians and, therefore, it was better to place the returned wafers in a decent place and to allow the "accidents" of the Eucharist to decay. After that, the superior continued, they could dispose of them, as was usually done with consecrated hosts. The local priest did as he was told and placed the hosts in a secure place in the church. Yet something drew the priest to keep visiting them. To his great amazement, he found that these consecrated wafers resisted not only the bandits' attempts to physically destroy them but also the forces of nature. As the printed chapbooks announced in excitement, these wafers proved to be unharmed by the passing of years and the difficult weather conditions. The priest informed his superior about the supernatural occurrence, and the latter invited higher ecclesiastical authorities to inspect the incorruptible wafers. After examination, these hosts were proclaimed an "evident miracle." Printed "true accounts" (relaciones verdaderas) helped propagate this Eucharistic miracle throughout the Iberian Peninsula and declared that this was a refutation of the "heretics" and a testimony of Christ's Real Presence in the Eucharist. Eventually, the so-called Sacred Forms of Alcalá became the subject of several religious plays, devotional images, and an enduring cult. Although the original miraculous hosts were lost during the Spanish Civil War, they are still venerated today in Alcalá in the special chapel commemorating the miracle. ${ }^{2}$

The history of the Sacred Forms of Alcalá can be conveniently divided into three distinct phases. A sacrilege was committed upon the host in at least two senses of the term: the sacred object was taken from its designated place and was then mistreated. This rejection of the sacredness of the host was then followed by a demonstration of its miraculous power, proving that, like Christ whose body it contained under the accidents of bread, it could not be destroyed. The story ends with the emergence of a new cult centered around a Eucharistic relic. In this sense, the narrative of the Sacred Forms of Alcalá is no different from various other tales of Eucharistic miracles that served as foundation myths for the establishment of shrines across Catholic Europe. As is widely known, in a significant number of these narratives Jews figured prominently as those who profaned the host. Some scholars have explained this tendency as a sort of defense mechanism. In this view, Christians projected their theological doubts and sentiments of guilt onto Jews, who then provided a confirmation of the complex doctrine of the Eucharist, as well

\footnotetext{
${ }^{2}$ For general information on the development of the cult, see María Evangelina Muñoz Santos, "La recuperación de una devoción secular: El culto a las 24 Santas Formas de Alcalá de Henares. Génesis y vicisitudes," in Patrimonio inmaterial de la Cultura Cristiana, ed. Francisco Javier Campos y Fernández de Sevilla (San Lorenzo del Escorial, 2013), 193-214.
} 
as their compulsion to reenact the deicide. ${ }^{3}$ Israel Jacob Yuval has added an important and suggestive perspective to this issue, demonstrating that the host profanation accusation developed in a context of a polemical dialogue between Christianity and Judaism. ${ }^{4}$ Further, Miri Rubin, in her magisterial analysis of the symbolic significance of these tales, has shown that as the Eucharist became a symbol of Christian communal identity, Jews were increasingly labeled as the archenemies of the Eucharist. Given that Jews had an ambiguous status in premodern Europe-living outside the Church but within Christian society, in the words of Gilbert Dahan - they proved to be a fruitful "object to think with" in order to mark difference..$^{5}$ In that sense, Rubin argued, Jewish host profanation was a story Christians told themselves in order to define what it meant to be a Christian. ${ }^{6}$

Rubin's broad survey follows the development of this anti-Jewish narrative from the early Middle Ages to the beginning of the modern era across Latin Christendom, including the Iberian Peninsula. In post-1391 Iberia, after the mass conversion of Jews to Christianity, a variant of this anti-Jewish narrative appeared when the accusation of host profanation was leveled against those Christians who were descendants of Jews. These New Christians, or conversos as they were commonly referred to, were frequently suspected of maintaining allegiance to the faith of their ancestors. As such, it was generally believed that like their forefathers, they, too, rejected Christ and the Eucharist and aimed to profane it. Against this backdrop, one may assume that the miracle of the Sacred Forms of Alcalá is yet another tale of Jewish/converso host profanation. Yet the printed accounts that spread the news about the miracle in Alcalá did not target New Christians whose ancestors were Jews. Rather, they specified that these New Christians were of Muslim origin. That is, they were what contemporaries labeled pejoratively moriscos, a term that modern scholars embrace as a convenient name for the Spanish Muslims who were forcibly converted to Christianity by royal decrees between 1502 and 1526, only to be ultimately expelled between 1609 and 1614 .

\footnotetext{
${ }^{3}$ Gavin I. Langmuir, "The Tortures of the Body of Christ," in Christendom and Its Discontents: Exclusion, Persecution, and Rebellion, 1000-1500, ed. Scott L. Waugh and Peter D. Diehl (Cambridge, UK, 2002), 287-309. And see similar claims in Peter Browe, "Die Hostienschändungen der Juden im Mittelalter," Römische Quartalschrift für Christliche Altertumskunde und Kirchengeschichte 34 (1926): 167-97; Lester K. Little, Religious Poverty and the Profit Economy in Medieval Europe (Ithaca, NY, 1983), 52-54.

${ }^{4}$ Israel Jacob Yuval, Two Nations in Your Womb: Perceptions of Jews and Christians in Late Antiquity and the Middle Ages, trans. Barbara Harshav and Jonathan Chipman (Berkeley, 2008), ch. 5.

${ }^{5}$ Gilbert Dahan, Les intellectuels chrétiens et les juifs au Moyen Âge (Paris, 1990), 104.

${ }^{6}$ Miri Rubin, Gentile Tales: The Narrative Assault on Late Medieval Jews (Philadelphia, 2004), 5.
} 
The reference to the moriscos in the chapbooks propagating the miracle of the Sacred Forms of Alcalá was not an exceptional case. On the contrary, the evidence mustered in the following pages testifies to the regularity with which Christians described Muslims and moriscos as enemies of the Eucharist in the late medieval and early modern Iberian Peninsula. The issue at stake, I believe, bears importance for broader consideration of Jewish exceptionalism in premodern Europe. As it stands, the history of the accusation of host profanation is by and large a history told from the point of view of increasingly conflictual relations between Christians and Jews. Rubin, for instance, has shown how the role of the Jew in these narratives changed throughout the Middle Ages from witness of Eucharistic miracle and, therefore, convertible to Christianity, to a bitter enemy of the host, who must be punished by death. More generally, scholars classify the host profanation accusation as part of the broader category of anti-Jewish libels. These hateful narratives that portrayed Jews as desecrating religious images, blaspheming against Christ and Christianity, poisoning wells and, of course, ritually murdering Christian children, were frequently used to justify violence against Jewish communities. Gavin I. Langmuir viewed these libels as an indication of the rise of "irrational" hatred towards Jews in the Middle Ages and as an important step on the road to modern antisemitism. ${ }^{7}$ But what happens to this grand narrative if these accusations were leveled against non-Jews as well?

Historians of Christian-Jewish relations in premodern Europe tend to gloss over the existence of accusations of host desecration leveled against non-Jews. Yet other groups, such as witches, heretics and, as we shall immediately see, Muslims, were occasionally charged with profaning the Eucharist. This very fact raises further questions that only a comparative perspective can fully answer. Were these accusations against the different groups essentially one and the same thing? Can we detect mutual influences between accusations leveled against one specific group and those made against others? And, finally, were accusations of host profanation leveled against non-Christians ultimately derived from the particular conditions of Christian society, regardless of the group accused? As a first attempt at exploring these questions, this essay interrogates some of the parallels and intersections between accusations of Jewish/converso host profanation and those leveled against Muslims and moriscos.

Thus far, not all attempts to examine the reciprocal interactions between Christian anti-Muslim and Christian anti-Jewish discourses have proved fruitful. In one such case, Allan and Helen Cutler dramatically asserted that "medieval anti-Semitism (and thus, indirectly, modern anti-Semitism as well,

\footnotetext{
${ }^{7}$ Gavin I. Langmuir, Toward a Definition of Antisemitism (Berkeley, 1990).
} 
which to a significant extent stems from medieval anti-Semitism) was primarily a function of medieval anti-Muslimism." 8 This sweeping statement, widely rejected in the scholarship due to its shaky methodological grounds, makes the need for a more careful historical analysis of the ways ChristianJewish and Christian-Muslim relations inform one another all the more urgent. More rigorous scholarly efforts have pointed to the changing status of the Jew in Christian polemics and theology after the twelfth century. These changes were related to broad structural transformations in European societies, including the struggle against Christian heresy but also, significantly, the intensification of the encounter with Islam. ${ }^{9}$ Studies devoted to what Jeremy Cohen has labelled "the Muslim Connection," however, have tended to explore influences in a single direction, namely from Christian polemics against Islam to Christian Adversus Iudaeos literature. This essay inverts this perspective and asks in what ways the anti-Jewish host profanation libel informed and intersected with similar accusations against Muslims and moriscos.

Some scholars of Christian-Muslim relations have pointed to Christian texts and images that represent Muslims as enemies of the Eucharist or as "infidel" witnesses to the truth it bears. ${ }^{10}$ In early modern Iberia, those focusing on what Louis Cardaillac once labeled the "polemical confrontation" between moriscos and Christians have long noted the aversion and even ridicule moriscos were reported to express towards the Eucharist. ${ }^{11}$ Nevertheless, to the best of my knowledge, there have been no attempts to view alleged

\footnotetext{
${ }^{8}$ Allan Harris Cutler and Helen Elmquist Cutler, The Jew as Ally of the Muslim: Medieval Roots of Anti-Semitism (Notre Dame, IN, 1986), 97. And see the criticism of Jeremy Cohen, “The Roots of Anti-Semitism?" Judaism 37 (1988): 240-42; Gilbert Dahan, "Cutlers' 'The Jew as Ally of the Muslim'," Jewish Quarterly Review 79 (1989): 370-77.

${ }^{9}$ See Jeremy Cohen, "The Muslim Connection or On the Changing Role of the Jew in High Medieval Theology," in From Witness to Witchcraft: Jews and Judaism in Medieval Christian Thought, ed. Jeremy Cohen (Wiesbaden, 1996), 141-62; idem, Living Letters of the Law: Ideas of the Jew in Medieval Christianity (Berkeley, 1999), 156-57; Ryan Szpiech, "Rhetorical Muslims: Islam as Witness in Western Christian Anti-Jewish Polemic," Al-Qantara 34 (2013): 153-85.

${ }^{10}$ See, for instance, Bernard Flusin, "Démons et Sarrasins: L'auteur et le propos des 'Diègèmata stèriktika' d'Anastase le Sinaïte," Travaux et mémoires 11 (1991): 381-409; Arietta Papaconstantinou, "Saints and Saracens: On Some Miracle Accounts of the Early Arab Period," in Byzantine Religious Culture: Studies in Honor of Alice-Mary Talbot, ed. Denis Sullivan, Elizabeth A. Fisher, and Stratis Papaiaonnou (Leiden, 2012), 323-38; Nirit Ben-Aryeh Debby, "St. Clare Expelling the Saracens from Assisi: Religious Confrontation in Word and Image," Sixteenth Century Journal 43 (2012): 643-65; Kristen Van Ausdall, "Art and Eucharist in the Late Middle Ages," in A Companion to the Eucharist in the Middle Ages, ed. Ian Christopher Levy, Gary Macy, and Kristen Van Ausdall (Leiden, 2012), 541-617, esp. 591-92.

${ }^{11}$ For some important points of departure, see Louis Cardaillac, Moriscos y cristianos: Un enfrentamiento polémico (1492-1640), trans. Mercedes García-Arenal (Madrid, 1979),
} 
Jewish/converso hostility towards the Eucharist in Iberia in conjunction with those texts and images that depicted Muslims and moriscos as enemies of the host. The problem, it would seem, is much wider than the specific issue of shared alleged hostility toward the Eucharist. In a pioneering essay, James Amelang described the separate historiographies of Jews/conversos and Mus$\mathrm{lim}$ /moriscos as living "with their backs to each other." 12 Thus, although both ethnoreligious groups experienced forcible conversion to Christianity, inquisitorial persecution, and expulsion in the same geographical space and in adjoining time periods, a comparative or holistic view has rarely been offered. ${ }^{13}$ For Amelang, in the final analysis, the histories of these two minorities, while comparable, were essentially distinct. There are good reasons to concur with this conclusion. Yet as scholars have recently demonstrated, there were also intersections and mutual influences between these histories. ${ }^{14}$ This essay presents further evidence along these lines, showing that in premodern Iberia, Christians grouped together these two minorities, compared and connected them, and even conflated them.

\section{The Eucharist and the Christian Imagination: Associations and Variations}

The emergence of the accusation of host profanation in medieval Europe is intertwined with the development of Eucharistic devotion. While the Eucharist was the focus of various rituals as well as a subject of intense theological discussion in the early and High Middle Ages, it was only in the thirteenth century that Eucharistic devotion gave birth to the accusation of Jewish host profanation. Two significant events mark the thirteenth century as the historical watershed of what came to be known as the Most Blessed Sacrament. In 1215, the Fourth Lateran Council declared that the consecrated wafer and wine were transubstantiated in the Eucharist into Christ's actual

290-301; Mercedes García-Arenal, Inquisición y moriscos: Los procesos del Tribunal de Cuenca (Madrid, 1978), 103-5.

${ }^{12}$ James S. Amelang, Parallel Histories: Muslims and Jews in Inquisitorial Spain (Baton Rouge, LA, 2013), $\mathrm{x}$.

${ }^{13}$ The important exception is David Nirenberg's Communities of Violence: Persecution of Minorities in the Middle Ages (Princeton, 1996), which remains a fundamental point of departure to the study of the intersections between Christian, Jewish, and Muslim histories in premodern Iberia.

${ }^{14}$ See, for example, Isabelle Poutrin, "The Jewish Precedent in the Spanish Politics of Conversion of Muslims and Moriscos,” Journal of Levantine Studies 6 (2016): 71-87; François Soyer, "The Recycling of an Anti-Semitic Conspiracy Theory into an Anti-Morisco One in Early Modern Spain: The Myth of El Vengador, the Serial-Killer Doctor," eHumanista 4 (2016): 233-55. 
body and blood; they were "truly contained in the sacrament of the altar under the forms of bread and wine." ${ }^{15}$ In 1264, Pope Urban IV instituted Corpus Christi, a highly solemn celebration including a Eucharistic procession, as a feast for the entire Catholic Church. With its incorporation into the collection of canon law known as the Clementines, which was issued in 1314 by Pope Clement IV and published by Pope John XXII in 1317, the feast of Corpus Christi became a truly universal celebration across Roman Catholicism. ${ }^{16}$ These doctrinal and liturgical developments were accompanied, indeed propagated, by a proliferation of Eucharistic miracles. In these miracles, which were included in compilations of exempla used by preachers as well as recorded in chronicles and displayed in visual representations, the consecrated host demonstrated supernatural powers: it cured the sick, was venerated by animals, and "behaved" like an animate being-bleeding, sweating, transforming into a child, and so forth-thus proving that the Eucharist indeed performed a miracle and transformed the bread and wine into something wholly different.

Within this genre, a specifically anti-Jewish accusation emerged, according to which Jews procured the Eucharistic host in order to abuse it, in clear repetition of the Passion. In these narratives, the abused host reacted miraculously to its profanation, thus leading to the conversion or the punishment of the Jew. The most famous of these tales, known as the "Billettes affair" of Paris, 1290, can serve as a general model for the entire subgenre. ${ }^{17}$ In most versions of the tale, it was a Christian woman who procured the consecrated host for the Jew. This woman was described as either the Jew's servant or, in the most influential version of the tale, the wife of a Christian debtor who was pushed to give the Jewish moneylender a consecrated host as pawn. Once the Jew acquired the host, he began to exercise his malicious plan against the body of Christ and, more broadly, against Christianity. In the Paris accusation, the Jew is described as abusing the host, stabbing it with a knife, throwing it into a fire and then into a cauldron of boiling water. The host bled in reaction to the knife attacks and, in some of the versions, was transformed through the encounter with fire and boiling water into flesh and blood. Christian authors offered different endings to this narrative. In some, the miracle of the host caused the Jew and his family to convert to Christianity. In yet other versions, after the sacrilege was discovered, the Jew was punished and

\footnotetext{
${ }^{15}$ Norman Tanner, ed., Decrees of the Ecumenical Councils, vol. 1, Nicaea I to Lateran V (London, 1990), 230.

${ }^{16}$ For a broad overview of the development of Eucharistic devotion and legislation, see Miri Rubin, Corpus Christi: The Eucharist in Late Medieval Culture (Cambridge, UK, 1991); Thomas M. Izbicki, The Eucharist in Medieval Canon Law (Cambridge, UK, 2015).

${ }^{17}$ For an overview of the "Billettes affair," see Rubin, Gentile Tales, 40-48.
} 
his house was transformed into a church. This last version reflects a certain historical reality: in 1295 Pope Boniface VIII authorized the Bishop of Paris to establish a church on the site of the alleged profanation. For centuries, this Parisian church kept a relic of the host believed to have been profaned by Jews. As in parallel cases, the accusation of Jewish host profanation served as a foundation myth for the erection of a Christian shrine which attracted devotees and pilgrims for its miraculous host-relic. ${ }^{18}$

This well-known narrative was widely disseminated throughout premodern Europe, where it appeared with adaptations in most of western and central Europe before the sixteenth century and later on mostly in eastern Europe. It became as well the subject of religious imagery, most famously Paolo Uccello's predella for the Corpus Domini Altarpiece in Urbino (1467-1468). ${ }^{19}$ A century before the Urbino Altarpiece was created, however, this antiJewish Eucharistic tale was already present in the Iberian Peninsula, where it appeared in judicial accusations against Jews and informed works of religious art. ${ }^{20}$ A visually striking example of this can be found in the Altarpiece of the Virgin attributed to the Serra brothers and made for the cloistered female convent of Santa María in Sigena (Huesca). The centerpiece of the painting presents the Virgin with the Christ Child holding a flower, surrounded by Saint Catherine of Alexandria, Mary Magdalene, and the portrait of the altarpiece's donor, Fray Fontaner de Glera, who was the convent's commander between 1365 and 1373 (fig. 1). While the Virgin occupies the center of the painting, the broader pictorial program of the altarpiece transmits strong Eucharistic resonances. At the center of the banco, that is, the lower panel of the altarpiece known in Italy as the predella, there is a Last Supper scene. Christ blesses a chalice above which appears a host, clearly in reference to the institution of the Eucharist (Mark 14:22-24; Matt 26:26-28; Luke 22: 19-20). Flanking the Last Supper are depictions of four Eucharistic miracles that were known to late fourteenth-century viewers. To the left of the Last Supper panel, the Serra brothers depicted two Eucharistic tales, the Miracle of the

\footnotetext{
${ }^{18}$ See Mitchell B. Merback, Pilgrimage and Pogrom: Violence, Memory, and Visual Culture at the Host-Miracle Shrines of Germany and Austria (Chicago, 2012); Caroline W. Bynum, Wonderful Blood: Theology and Practice in Late Medieval Northern Germany and Beyond (Philadelphia, 2007).

${ }^{19}$ Marilyn Aronberg Lavin, "The Altar of Corpus Domini in Urbino: Paolo Uccello, Joos Van Ghent, Piero della Francesca," Art Bulletin 49 (1967): 1-24. See also Dana E. Katz, The Jew in the Art of the Italian Renaissance (Philadelphia, 2008), ch. 1.

${ }^{20}$ For a discussion of the complex history of the circulation of the host profanation accusation in late medieval Iberia, see Yonatan Glazer-Eytan, "Jews Imagined and Real: Representing and Prosecuting Host Profanation in Late Medieval Aragon," in Jews and Muslims Made Visible in Christian Iberia and Beyond, 14th to 18th Centuries: Another Image, ed. Borja Franco Llopis and Antonio Urquízar-Herrera (Leiden, 2019), 40-69.
} 


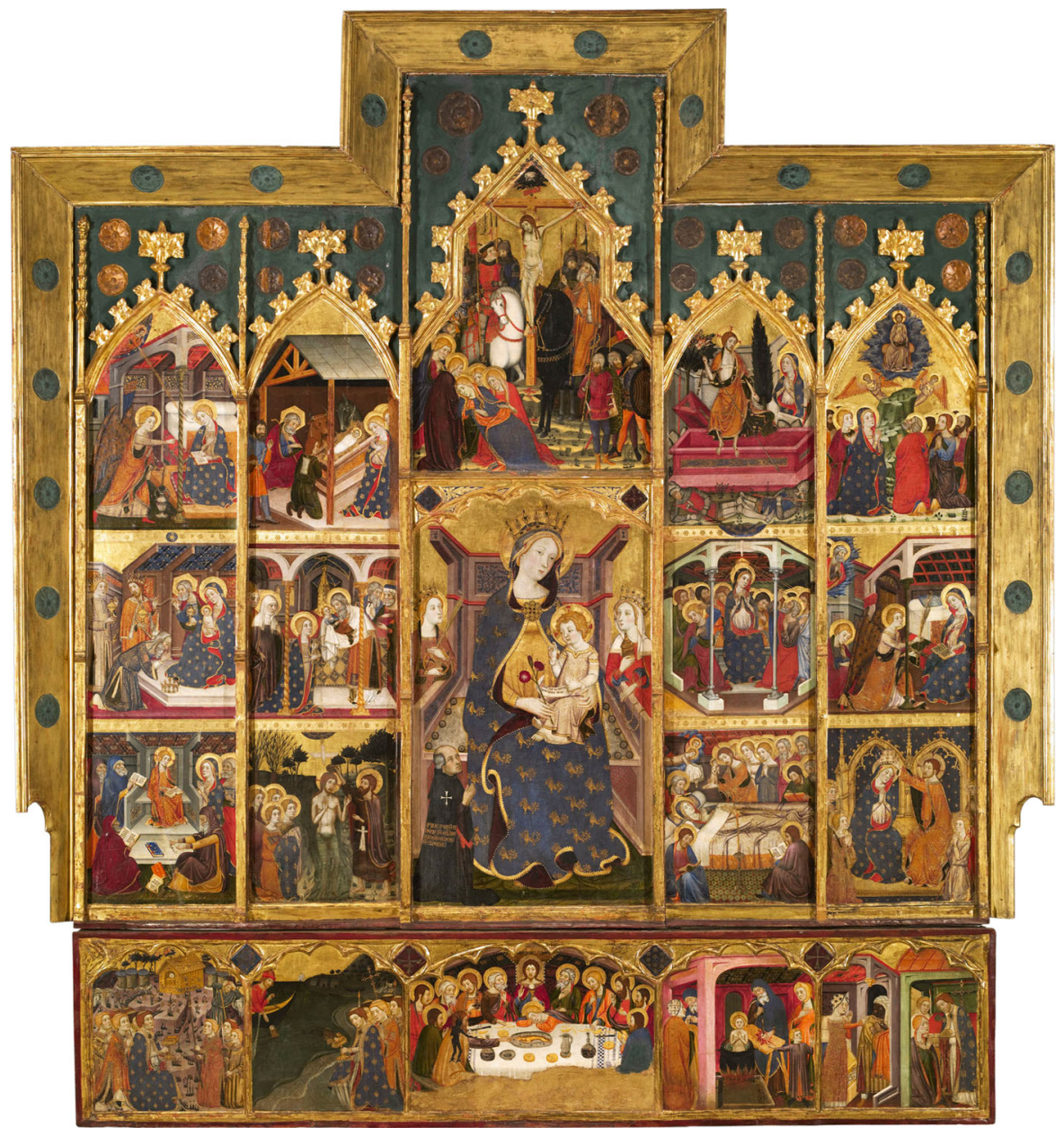

Figure 1. Jaume Serra, Altarpiece of the Virgin, ca. 1367-1381, Museu Nacional d'Art de Catalunya (Barcelona). https://www.museunacional.cat/en/colleccio/altarpiece-virgin/jaumeserra/015916-cjt

Bees and the Miracle of the Fisherman. In both of these widely circulated tales, the consecrated host is prompting natural miracles: bees become hyperproductive after the host is placed in a hive; a fish is returning the host to a once sinful, now repentant fisherman who had thrown the consecrated wafer into the sea years before. ${ }^{21}$ To the right of the Last Supper panel there are two panels representing Eucharistic miracles happening after a profanation

\footnotetext{
${ }^{21}$ See discussion, with further references to textual sources and visual parallels, in Paulino Rodríguez Barral, La imagen del judío en la España medieval: El conflicto entre cristianismo y judaísmo en las artes visuales góticas (Barcelona, 2008), 197-200.
} 


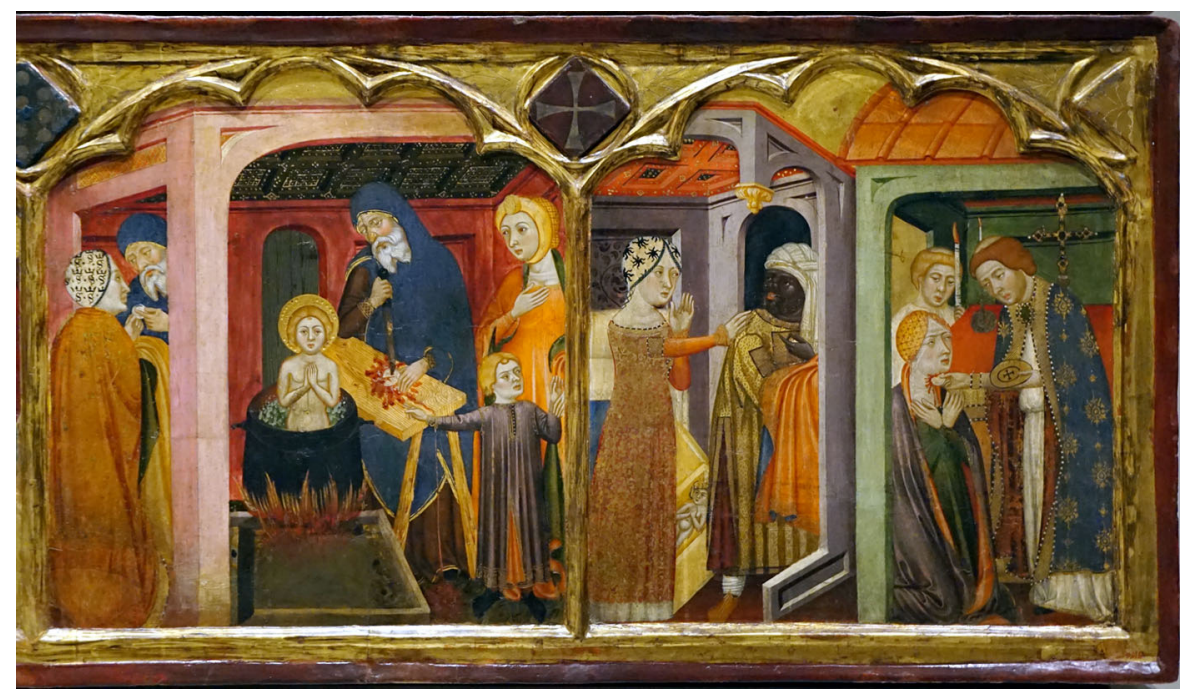

Figure 2. Jaume Serra, Altarpiece of the Virgin, detail, Museu Nacional d'Art de Catalunya (Barcelona)

of the host. In the panel closer to the Last Supper, the Serra brothers depicted the Paris host profanation tale (fig. 2). The panel presented the narrative in two steps. On the left, the sacrilegious transaction takes place between the Christian woman and the Jewish moneylender. On the right, the Jew stabs the host, which bleeds in response. The host was also thrown into a cauldron of boiling water, where it was transformed into a child, a recurring trope in Eucharistic miracles. The Jew's wife and child are depicted somewhat passively as witnesses to the desecration and miracle, leaving them potentially open to conversion to Christianity.

This representation of host profanation is quite similar to many others throughout the Christian world. Commissioned not long after Eucharistic liturgy was introduced to Aragon, it fits neatly into the narrative established by Rubin, according to which growing devotion to the Eucharist went hand in hand with the increasing tendency to mark the Jew as the Eucharist's enemy. Rubin not only integrates an analysis of this altarpiece into her argument but also uses a detail from it on her book cover, thus clearly framing this painting as yet another example of the tale about the Jews told by Christians for Christians. Yet the last scene represented in the banco of this altarpiece may force us to nuance this sweeping narrative. Adjacent to the Serras' depiction of the tale of Jewish host profanation from Paris 1290 is another Eucharist miracle (fig. 2). This panel once again displays a narrative in two steps. In the first step, a Christian woman, depicted in almost exactly the same way as the Parisian woman procuring the host for the Jewish moneylender, engages in conversation with a man. Yet this man has none of the stereotypical 
attributes of Jews in Christian religious imagery. Instead, he is represented as dark-skinned, with a flat nose and a curly beard. He is dressed in lavish golden attire and wears a white turban. In short, the representation of this man clearly corresponds to the way premodern Iberians depicted Muslims. In the background, an infant lies inside a small crate. The subsequent scene portrays the same woman, who is now dressed in a more modest manner, taking communion from a priest. However, the host cuts through her throat in a way that we may imagine leads to her death.

The meaning of this peculiar image may be interpreted with the help of a literary work titled The Mirror (Spill, ca. 1460), which was written by the Valencian physician and author Jaume Roig (d. 1478). This rather misogynist book offers advice based on Roig's personal experiences about how to avoid the dangers posed by women. ${ }^{22}$ In the Mirror, Roig narrates a case he claimed to have witnessed in Zaragoza in which a woman seeking to regain her husband's love turned to a Muslim sage (un serrahy/ llur alfaqui) for help. ${ }^{23}$ The Muslim sage then said that he could help her in exchange for both monetary payment and a consecrated host. The woman followed the sage's request and went to the church of San Miguel in Zaragoza. She took communion falsely and, "as if she wanted to wipe her mouth," removed the consecrated wafer from her mouth and secretly placed it in a little case. When she brought the stolen host back to the Muslim sage and he, enthusiastically, opened the case, they both discovered that the consecrated wafer had been transformed into a "beautiful infant, all glowing and luminous." At this sight, the woman became "frightened, deranged, and out of her mind." The Muslim sage was first surprised. But then, this "morisco, an evil dog," as Roig calls him, suggested burning the case with the child-host. The woman, now called a "renegade" by Roig, followed the Muslim's advice and burned the case until it was charred. Yet the glowing child remained undamaged, despite the woman's insistent efforts. Not knowing what to do and "blinded by ire," the woman went in search of the sage, who was attending the Friday prayers at the local mosque. The Muslim sage was overwhelmed by fear and urged the woman to go with him to Zaragoza's cathedral and to confess their sins. If the Christian authorities spared both of them, he continued, he would "renounce Muhammad." The bishop found out about this incident. He gathered the city's ecclesiastical and secular notables in order to preach to them and explain how this "horrible" case was in fact a "confirmation of our faith." After a solemn

\footnotetext{
${ }^{22}$ I follow here Paulino Rodríguez Barral, who, to the best of my knowledge, is the first to propose this association. See idem, La imagen del judio, 200-201.

${ }^{23}$ For this and subsequent quotations, see María Celeste Delgado-Librero, "The Mirror" of Jaume Roig: An Edition and an English Translation of MS. Vat. Lat. 4806 (Tempe, AZ, 2010), 109-13, verses 3500-3819; English translation, 304-6.
} 
procession, the miraculous host-turned-into-a-child was taken and placed in the cathedral, at the altar of St Valerius, a patron saint of Zaragoza. When the priest celebrated the Eucharist, the "holy body" was transformed once again into the original form of the wafer. Roig concludes that this case "contradicted the evil infidels ... and it was shameful especially for women." And thus, while Roig did not specify the fate of the Muslim, this miraculous Eucharistic narrative terminates in the Spill with the death of the woman by lightning.

There are some problems in drawing too direct a line between the painted panel in the Altarpiece of the Virgin in Sigena and Roig's tale as it is told in the Spill. The first problem is the lack of complete correspondence between the narratives. The first scene depicted in the Sigena panel, which represents the woman and the Muslim sage anxiously discussing what to do with the host-child in the case, perfectly echoes Roig's narrative. However, the second scene, which displays the sinful woman's end, is clearly different from the closure of the narrative in the Spill. Another problem with the comparison between the Sigena Altarpiece and the Spill is the fact that the latter was written around a century after the painting and, additionally, refers to a miracle that allegedly happened in Zaragoza in 1427. Given that the Sigena Altarpiece was painted between 1365 and 1373, it is clear that it did not depict the same miraculous occurrence.

The possible solution to this conundrum is to assume that an earlier tradition circulated in the Iberian Peninsula. This tradition was either transmitted orally or through a written account that did not survive. This hypothetical earlier tradition could have been an adaptation of Cantiga 104 in Alfonso $\mathrm{X}$ 's Cantigas de Santa María. This Cantiga begins with a squire's mistress who is saddened when her lover marries another. The Cantiga then tells how the woman sought the advice of her neighbors, without specifying whether they were non-Christians, and that the latter suggested she steal a host. This Cantiga clearly implies that the stolen host was intended for magical purposes, a well-known trope in medieval lore. ${ }^{24}$ After procuring the host, the woman secretly placed it in her headscarf. There, the host started bleeding profusely. When other people reacted to seeing the blood flowing from her headscarf, the woman realized the miraculous nature of the incident, repented, and joined a convent as a nun. While the Cantiga neither refers to a Muslim sage nor ends with a divine punishment inflicted on the woman, its

\footnotetext{
${ }^{24}$ Alfonso X, el Sabio, Cantigas de Santa María, ed. Walter Mettmann, 3 vols. (Madrid, 1986-1989), Cantiga 104, 2:18-20; Jaime Ferreiro Alemparte, "Fuentes germánicas en las 'Cantigas de Santa María' de Alfonso X El Sabio," Grial 9, no. 31 (1971): 31-62, at 45-46, 48-49. See also Peter Browe, "Die Eucharistie als Zaubermittel im Mittelalter," Archiv für Kulturgeschichte 20 (1930): 134-54, at 135-37.
} 
narrative structure strikingly resembles both the scene depicted in the Sigena Altarpiece and Roig's Spill.

It is possible, then, to postulate a precursor to the narratives in the Sigena Altarpiece and the Spill in which a Christian woman seeks to regain her lover's affection and turns for help to a certain sorcerer who can produce a love potion with a consecrated host. From this point the narrative can diverge in two directions. The more forgiving closing has the woman repenting and returning to the fold of the church. In the more vengeful resolution, the woman is put to death. In that analysis, the difference between the visual version of Sigena and the textual version of Roig is relatively minor. They are variations on the same theme: in both, the sinful, sacrilegious woman is receiving divine punishment. ${ }^{25}$ As a matter of fact, in one of the later retellings of this Eucharistic miracle, the Muslim sage converted to Christianity and the woman asked for absolution. ${ }^{26}$ We thus can see the story's ending as one of the more malleable elements of the narrative, open to at least two types of closure, each of which may involve variations of detail.

The appearance in the Sigena Altarpiece and in Roig's Spill of the figure of the Muslim sage poses a problem of a different order. Given the propensity of Christian Eucharistic tales to depict the person who obtains the consecrated host as a Jew who seeks to abuse it, as well as the long-standing association of Jews with magic in medieval Europe, the figure of the Muslim sage from Zaragoza may seem surprising. In her analysis of Roig's tale, Francesca Español Bertrán has argued that the reference to the Muslim sage resulted from "contamination" between the usual tale targeting the sacrilegious Jew, on the one hand, and contemporary Valencian preoccupations with Muslim coastal raids, in which churches were desecrated, on the other. ${ }^{27} \mathrm{I}$ believe, however, that the connections between Jew and Muslim in the medieval Iberian Christian imagination can be traced to an earlier period. In fact, the similar roles Jews and Muslims occupy in the Sigena Altarpiece show that the connections between the two run deeper than a particular fifteenth-century Valencian context.

Evidence for the similarities between Jews and Muslims in Eucharistic tales can be gleaned from the language employed by Roig. To begin with, Roig insultingly dubs the Muslim sage an "evil dog." This pejorative term

\footnotetext{
${ }^{25}$ Rodríguez Barral, La imagen del judio, 201 n. 200, gives several literary parallels.

${ }^{26}$ José Antonio Hebrera y Esmir, Vida prodigiosa del ilustrissimo y venerable D. Martin García, obispo de Barcelona (Zaragoza, 1700), 1:30. My thanks to Teresa Soto González for bringing this source to my attention.

${ }^{27}$ Francesca Español Bertrán, "Ecos del sentimiento antimusulmán en el 'Spill' de Jaume Roig," Sharq al-Andalus 10-11 (1993-1994): 325-45.
} 
was repeatedly used in medieval and early modern Spanish sources with reference to Muslims. ${ }^{28}$ At the same time, medieval Christian devotional works and religious art built on Ps 21:17 (quoniam circumdederunt me canes multi) in describing Christ's Jewish tormentors as dogs. ${ }^{29}$ Another significantly ambiguous term is alfaquí, which Roig uses to describe the Muslim sage. The etymology of the term might be related to the Arabic Faqīh (فَقِقِيَ), understood today mostly as an expert in Islamic jurisprudence. Medieval usage of the term, however, was looser. Most interestingly, perhaps, is the fact that the term did not refer exclusively to Muslims. For example, in 1220 Pope Honorius III granted protection to the Jewish physician of James I of Aragon, Isaac Benveniste, to whom he referred to as "alfakimo karissimi." ${ }^{30}$ In other contemporary Aragonese documents, the term "alfaquín" or "our alfaquín" is widely used in reference to Jewish officials in the service of the Crown, whether physicians, advisors, ministers, or some combination thereof. ${ }^{31} \mathrm{Fi}$ nally, in the Cantigas de Santa María, the Alfonsine text employs the term "alfaquín" in reference to a blasphemous Jewish sage. ${ }^{32}$ Thus, while Roig's alfaquí is clearly a Muslim, the term could also refer to Jews.

The issue here is not simply the shared designation as alfaquí but rather the association of both Jews and Muslims with potentially dangerous wisdom. The Christian association between Jews and magic is well known thanks to the seminal work of Joshua Trachtenberg, who argued that this belief led to the emergence of anti-Jewish libels such as the host desecration. ${ }^{33}$ But in the Middle Ages, magic was not exclusively associated with Jews. Christian authors, especially from the twelfth century onwards, associated Muslims with

\footnotetext{
${ }^{28}$ For instance, Cantiga 192 refers to Prophet Muhammad as a dog (Mafomete cão); see Alfonso X, Cantigas de Santa María, 2:218-23, at 221, v. 104. Jaume Bleda, who is discussed below, refers to the moriscos as "rabid dogs" in his Corónica de los moros de España (Valencia, 1618), 882.

${ }^{29}$ Kenneth Stow, Jewish Dogs: An Image and Its Interpreters; Continuity in the CatholicJewish Encounter (Stanford, 2006); James Marrow, "Circumdederunt Me Canes Multi: Christ's Tormentors in Northern European Art of the Late Middle Ages and Early Renaissance," Art Bulletin 59 (1977): 167-81.

${ }^{30}$ Shlomo Simonsohn, The Apostolic See and the Jews, vol. 1, Documents: 492-1404 (Toronto, 1988), 108-9 n. 105, and see also the other related documents which employ similar terminology in 109-10 nn. 106-7.

${ }^{31}$ See a short discussion in Jerome Lee Shneidman, "Jews in the Royal Administration of Thirteenth Century Aragon," Historia Judaica 21 (1959): 37-52, esp. 39-40, where he suggests that the etymology of alfaquí is derived from al-Hakim, that is, the "wise" or the "learned."

${ }^{32}$ Alfonso X, Cantigas de Santa María, 2:30-33, at 30, v. 9.

${ }^{33}$ Joshua Trachtenberg, Jewish Magic and Superstition: A Study in Folk Religion (New York, 1939). But see now Katelyn N. Mesler, "Legends of Jewish Sorcery: Reputations and Representations in Late Antiquity and Medieval Europe" (PhD diss., Northwestern University, 2012).
} 
medicine, astrology, and magic, and Muhammad himself was described as a trickster who performed false miracles. ${ }^{34}$ This common association of Jews and Muslims with magic led in some cases to striking conflations. An example of this may be found in one of the versions of the proto-Faustian legend, the Miracle of Theophile. In this legend, Theophile, a disappointed Christian, seeks the help of a Jewish sorcerer, who functions as an intermediary with the devil. Theophile makes a pact with the devil, only later to repent it and ask for the Virgin's help. He is eventually forgiven and his contract with the devil is annulled. For our purposes, it is significant that in the version written ca. $1260-1270$ by the French poet Rutebeuf, the intermediary is called "Salatin," a name with evident Arab-Muslim connotations. As Gilbert Dahan has shown, Rutebeuf's text united the traditional Jewish enemy with the contemporary thirteenth-century Muslim enemy, both representing a religious Other who possesses dangerous wisdom. ${ }^{35}$

Ultimately, the Altarpiece of the Virgin in Sigena provides the most powerful evidence for the close association of, and even similitude between, Jews and Muslims in the premodern Iberian Christian imagination. While the sinful Christian woman who sacrilegiously procures the host is a constant in the different versions of the tale, the "infidel," who by mistreating the host eventually proves its power, may be either Jew or Muslim. Indeed, the close proximity in the Sigena Altarpiece of visual depictions of the Jewish host profanation of Paris and the Muslim host profanation of Zaragoza clearly indicates that to Christian eyes Jews and Muslims belonged to the same broader category and might even be prone to conflation. Admittedly, there are evident differences between the Jew and the Muslim in the Sigena Altarpiece. The former treated the host as an exchangeable good and thus fulfilled specific Christian stereotypes about Jewish materialism. In addition, it was only the Jew who was represented as directly and unabashedly attacking the host and thereby repeating the Passion. The Muslim, whose intended sorcery with the host can be contrasted with the priest and the true miracle of Eucharist, is depicted as distressed when his plot fails. These differences may be attributed to the unique place of the Jew in the premodern Christian imagination, from accused perpetrator of deicide to necessary element in salvation history. The

\footnotetext{
${ }^{34}$ See, for instance, John V. Tolan, Saracens: Islam in the Medieval European Imagination (New York, 2002), ch. 6, where the author compares this image of Muhammad as trickster to that of Jesus in the Toledot Yeshu narratives.

${ }^{35}$ Gilbert Dahan, "Salatin, du Miracle de Théophile de Rutebeuf," Le Moyen Âge 83 (1977): 445-68. For another case of literary conflation of Jews and Muslims, see the interesting essay by Michael Mark Chemers, "Anti-Semitism, Surrogacy, and the Invocation of Mohammed in the 'Play of the Sacrament', Comparative Drama (2007): 25-55. Less substantial are Sheila Delany, "Chaucer's Prioress, the Jews, and the Muslims," Medieval Encounters 5 (1999): 198-213, and Sophia Rose Arjana, Muslims in the Western Imagination (Oxford, 2015), ch. 2.
} 
figure of the Muslim cannot easily fulfill these functions. Perhaps for that reason, the visual representation of Muslims in Christian art is relatively scarce in comparison to that of Jews. But at least in the Sigena Altarpiece, both Jew and Muslim are represented as hostile to the salvific message of Christ. In the final analysis, these two "infidels" confirm-paradoxically, through their mistreatment of the host - the truth of the Church's teaching about the Eucharist.

\section{Minorities under Christian Rule: Coalescence and Resemblance}

The tendency to view both Jews and Muslims as potential enemies of the Eucharist is equally attested in medieval ecclesiastical and secular legislation. Here we are dealing not only with a fictional Jew or Muslim, but rather with flesh and blood ethnoreligious minorities who lived within Christian society. The legal sources discussed here reflect not so much the workings of the Christian imagination as late medieval and early modern sociopolitical issues. A case in point were Eucharistic processions, which gave rise across premodern Europe to anxieties about the possible contamination of the host. These concerns repeatedly targeted Jews, whose proximity to the Eucharistic wafers, the liturgical vessels, or the monstrance was considered a threat. ${ }^{36}$ But here, again, there is ample evidence of parallel anxieties with regard to Muslims.

Canon 68 of the Fourth Lateran Council is an important starting point. The canon is usually cited because it decreed that "Jews and Saracens" ought to wear distinctive clothing throughout Christendom to distinguish them from Christians. The canon, however, also specified that on Easter Sunday and the last three days of the Holy Week, Jews and Muslims may not appear in public, specifically because they dress in rich attire while Christians are mourning in commemoration of the Passion. ${ }^{37}$ Sentiments akin to those expressed in this canon also appear in Iberian ecclesiastical and secular legislation. Some late thirteenth- and fourteenth-century Iberian laws used broad categories to discuss the dangers Jews and Muslims posed to the Eucharist. For instance, in a Valencian synod held in 1278, Bishop Jazperto de Botonach forbade the selling of liturgical vessels, especially the Eucharistic chalice, to "infidels"

\footnotetext{
${ }^{36}$ Rubin, Corpus Christi, 35-49.

${ }^{37}$ Decrees of the Ecumenical Councils: Nicaea I to Lateran V, 266. On the increasing linking of Jews and Muslims in ecclesiastical legislation in the twelfth and thirteenth century, see Benjamin Z. Kedar, "De iudeis et sarracenis: On the Categorization of Muslims in Medieval Canon Law," in idem, The Franks in the Levant, 11th to 14th Centuries (Aldershot, UK, 1993), 207-13; James M. Powell, "The Papacy and the Muslim Frontier," in Muslims under Latin Rule, 1100-1300, ed. James M. Powell (Princeton, NJ, 1990), 175-203, esp. 186-93.
} 
(infidelibus). The broad category used here was perhaps primarily a reference to Jews, but it might certainly also refer to Muslims, who constituted a significant population in Valencia. Indeed, less than forty years later in the same city, King James II of Aragon (d. 1327) ordered that Jews and Muslims ought to either genuflect or remove themselves when the host was carried in the city's streets. ${ }^{38}$ Since the Feast of Corpus Christi was only introduced to Valencia in the 1320s, we can assume that the reference was to the ritual of the Viaticum, during which the Eucharist is taken to a person nearing his death. Be that as it may, it is clear that the tenor of this legislation reflects a concern about the disruption of the Eucharistic rituals by both Jews and Muslims.

Almost exactly the same legislation can be found in medieval Castile. Alfonso X's massive legal compendium, the Siete Partidas (composed around the mid-thirteenth century), declared that "Jews and Moors" ought to kneel down in front of the Eucharist like Christians, since "this is the truth and there is no other." If they choose not to do so, they should leave the street so that the clergy "could pass without any impediment." 39 About a century later, King Juan I promulgated a decree in the Cortes of Briviesca in 1387 which stated that "Jews and Moors should not dare to be in the street when Corpus Christi processions pass, and if one of them is caught he will be arrested by anyone and brought before a tribunal." This decree was later incorporated in Alfonso Díaz de Montalvo's Ordenanzas Reales (1484), one of the major legal compendia produced during the reign of the Catholic Kings; it thus informed secular legislation over the entire course of the early modern Spanish Monarchy. ${ }^{40}$ Castilian synodal legislation of the later Middle Ages went beyond the special occasion of the Eucharistic processions to speak of the interiors of churches as endangered sites. For example, the Synod of Cuenca declared in 1446 that "no Jew or Moor should dare to be present in the Church when Mass is said, and any Christian who defends them will incur a sentence of excommunication." ${ }^{41}$ Needless to say, these normative texts do not necessar-

\footnotetext{
${ }^{38}$ For Botonach's legislation, see Ignacio Pérez de Heredia y Valle, Sínodos medievales de Valencia: Edición bilingüe (Rome, 1994), 139-41. For Jaume II's legislation, see Aureum opus regalium privilegiorum civitatis et regni Valentie: Cum historia cristianissimi Regis Jacobi (Valencia, 1515), fol. 57r. Both are quoted in Mark Meyerson, Jews in an Iberian Frontier Kingdom: Society, Economy, and Politics in Morvedre, 1248-1391 (Leiden, 2004), 90 n. 93 and $85 \mathrm{n}$. 76, respectively.

${ }^{39}$ Alfonso X, Las Siete Partidas del Rey Don Alfonso el Sabio, cotejadas con varios códices antiguos por la Real Academia de la Historia (Madrid, 1807), 1.4.119.

${ }^{40}$ Alfonso Díaz de Montalvo, Ordenanzas Reales de Castilla o Libro de las Leyes (Seville, 1495), 1.1.3.

${ }^{41}$ Antonio García y García, ed., Synodicon hispanum. X: Cuenca y Toledo (Madrid, 2011), 321 n. 191: "Que ningund judio nin moro non sea osado de estar en la iglesia en tanto que se dize la misa. E si algund christiano los defendiere, que por ese mesmo fecho incurra en sentencia descomunion." Cf. Rubin, Gentile Tales, 31 n. 120.
} 
ily reflect enforcement in practice. Yet the coexistence of Jews and Muslims in the same legal clauses aiming to establish order during Eucharistic celebrations strongly indicates that the two ethnoreligious groups were viewed analogously in premodern Christian Iberia.

Admittedly, lumping together Jews and Muslims in laws dealing with the Eucharist was still far from accusing one group or the other of host profanation. Yet in particularly tense moments, Christians transformed what they saw as the potential danger to Christian society posed by Jews and Muslims into accusations that they had actually inflicted harm. During the second half of the fifteenth century, when Castile was immersed in civil strife, the opposition to the rule of Juan II (and later to Enrique IV) targeted the allegedly favorable attitudes of these monarchs to the Jewish and Muslim minorities. So, for instance, in a document known as the Sentence of Medina del Campo (1465), the noble faction rebelling against Enrique IV's rule demanded that all Jews and Muslims in the royal court should be thrown out of Castile and their property taken. They also declared that an Inquisition against the kingdom's "bad Christians" (probably referring to backsliding Jewish converts to Christianity) should be established. Most importantly for our purposes, the Sentence warned that "some Jews and Moors" were able to procure the consecrated host and other consecrated things for the sake of "performing some spells (maleficios) in injury to Our Lord and to His Holy Church and our faith." "Bad Christians" also participated in some of these host desecrations, the Sentence added. The nobles leading the rebellious faction demanded that such persons be judged heretics. ${ }^{42}$

The accusation of joint Jewish-Muslim host profanation conspiracy in the Sentence of Medina del Campo had clear political motives. Once again, however, it was not a unique case but rather part of a broader discourse. The host accusation in the Sentence clearly echoes other documents from the midand later-fifteenth century that criticize the Castilian government by attacking conversos. For example, Marcos García de Mora, one of the leaders of the 1449 Toledo Rebellion during which New Christians of Jewish origin were specifically targeted, included in his memorial a list of crimes committed by the conversos. Among them, he claimed that some clergymen of Jewish ancestry sold consecrated hosts and other liturgical objects to "Jews and other people and infidels." 43 Scholars are familiar with the tendency of Spaniards

\footnotetext{
${ }^{42}$ Fritz (Yitzhak) Baer, Die Juden im Christlichen Spanien, pt. 1, Urkunden und Regesten, vol. 2, Kastilien, Inquisitionsakten (Berlin, 1936), 331 n. 123.

${ }^{43}$ Eloy Benito Ruano, "El Memorial contra los Conversos del Bachiller García de Mora," Sefarad 17 (1957): 331. For a recent analysis of this important text, see Rosa Vidal Doval, "'Qui ex Iudeis sunt': Visigothic Law and the Discrimination against Conversos in Late Medieval Spain," in Forced Conversion in Christianity, Judaism and Islam: Coercion and Faith in Premodern Iberia and Beyond, ed. Mercedes García-Arenal and Yonatan Glazer-Eytan (Leiden, 2019), 60-85.
} 
to scapegoat Jews and New Christians of Jewish origin during the tumultuous fifteenth century. Yet it is telling that Mora's memorial, when accusing Jews of sacrilege, lumped them together with other, unspecified accomplices, and that the Sentence of Medina del Campo explicitly named Muslims along with Jews as enemies of the Eucharist.

The dramatic events of the expulsion of the Jews in 1492 and the forcible conversion of Muslims to Christianity in the first decades of the sixteenth century created a new situation. As Jews and Muslims were no longer permitted in Iberia, Christian anxieties migrated from the problem of "infidelity" to the problem of the alleged heresy and apostasy of those New Christians of Jewish or Muslim origin. The yoking together of people of Jewish and Muslim origin that was prevalent in medieval legislation is rarely found in records of the Spanish Inquisition, which had the jurisdiction over baptized Christians suspected in crimes against the faith. This is partly due to the different chronology of inquisitorial prosecution of conversos and moriscos, respectively. Whereas the Spanish Inquisition began in 1481 its activity as a tribunal dedicated to the problem of "judaizing" Christians, around the third decade of the sixteenth century persecution of conversos waned and was replaced by concerns about "illuminists" (alumbrados) and "Lutherans." In contrast, the Inquisition did not operate intensely against the supposed danger of cryptoIslam until the second half of the sixteenth century. At this point, the number of inquisitorial trial records dealing with conversos diminished significantly. Indeed, only in the last few decades of the morisco presence in Spain did the Inquisition resume its operations against New Christians of Jewish origin, this time against conversos who had migrated from Portugal by the thousands after 1580. These changing patterns of inquisitorial persecution explain to some extent why inquisitors rarely refer to conversos and moriscos as companions in crime.

Nevertheless, there is evidence suggesting that Christian anxieties produced very similar accusations of acts of irreverence towards the Eucharist against both groups. In the first decades of inquisitorial activity in Spain, roughly between 1481 and 1520, we find numerous denunciations accusing New Christians of Jewish origin of avoiding, disrespecting, and even profaning the Eucharist. In some trial records, conversos were accused of spitting during Mass, refusing to kneel down, or making disrespectful gestures when the host was elevated. In others, conversos were reported to have refrained from swallowing the host and later spitting it out. Some were accused of placing the consecrated wafer in their shoes so that they would tread on it throughout the day. Conversos were also accused of making sacrilegious remarks about the Mass, to the effect that it was a joke, or that the host was a little white cake, or that the Eucharist was a fraud-for example, by reciting 
the ritual formula "bread and wine I see, in the Law of Moses I believe" (pan $y$ vino veo, en la Ley de Moisen creo). ${ }^{44}$

Without entering into the thorny issue of the historical trustworthiness of these denunciations, it is evident that they reflect a widespread concern among "Old Christians": namely, that conversos were not only Jews in Christian garb but that they also were hostile to Christianity. Of course, Jews were accused in the past of hostility to Christianity, but it became more threatening when they entered Christian society. The accusations of sacrilegious statements about Catholic worship in general and the Eucharist in particular were thus a powerful weapon in the hands of those who wanted to harm New Christians of Jewish origin. ${ }^{45}$ This was precisely what happened in one of the most infamous campaigns of the early days of the Inquisition against "judaizers," that of the inquisitor Diego Rodríguez Lucero in Córdoba between 1499 and 1507. This inquisitor reported to his superiors that the conversos of Córdoba were secretly congregating to hear anti-Christian sermons from a man named Alonso de Membreque. According to the inquisitorial report, Membreque, who was dressed ceremoniously in white, made an altar and performed rituals intended to negate the Mass (hazia çiertas çerimonias contrafaziendo la Misa) ${ }^{46}$ On a different occasion, the conversos led by Membreque performed what the inquisitors considered to be a ritual of "Jewish cleansing." Membreque ordered the conversos to vomit the consecrated wafers they had been compelled to ingest, and to do so in the house's "dirtiest place." On yet another occasion, he produced a consecrated host. Then, states the report, Membreque and the assembled conversos took the host, tore it to pieces, threw it on the floor, and trampled it underfoot. Finally, they threw it into a latrine (neçesaria). While Lucero's anti-converso

\footnotetext{
${ }^{44}$ The quote is taken from Carlos Carrete Parrondo, "Melancholy among the Conversos of Castile and the Expulsion of 1492" [in Hebrew], in Jews and Conversos at the Time of the Expulsion, ed. Yom Tov Assis and Yosef Kaplan (Jerusalem, 1999), 184-85. For some further references see Haim Beinart, Conversos on Trial: The Inquisition in Ciudad Real [in Hebrew] (Tel Aviv, 1965), 196-97, 228-31; David M. Gitlitz, Secrecy and Deceit: The Religion of the Crypto-Jews (Albuquerque, NM, 1996), 148-52; Gretchen D. Starr-Lebeau, In the Shadow of the Virgin: Inquisitors, Friars, and Conversos in Guadalupe, Spain (Princeton, NJ, 2003), 63-64.

${ }^{45}$ For a broader discussion of this issue, see Yonatan Glazer-Eytan, "Incriminating the Judaizer: Inquisitors, Intentionality, and the Problem of Religious Ambiguity After Forced Conversion," in García-Arenal and Glazer-Eytan, Forced Conversion in Christianity, Judaism and Islam, 235-65.

${ }^{46}$ Archivo General de Simancas, Estado, 12, fols. 392-93. The document was transcribed by Rafael García y García de Castro, Virtudes de la Reina Católica (Madrid, 1961), 440-43, app. 18. A Hebrew translation and commentary is provided by Haim Beinart, "A Prophesying Movement in Cordova in 1499-1502," Zion 4 (Jerusalem, 1979), 190-200. See also John Edwards, "Elijah and the Inquisition: Messianic Prophecy among Conversos in Spain, c. 1500," Nottingham Medieval Studies 28 (1984): 79-94.
} 
campaign met resistance and ultimately, in 1508, this inquisitor was deposed from his office, Christian concerns about conversos mistreating the Eucharist and the vulnerability of conversos to such denunciations persisted.

When the Inquisition finally began to fully operate against the converted Muslims in the second half of the sixteenth century, it made similar accusations of sacrilegious behavior towards the Eucharist against them. As in the case of the conversos, accusations of sacrilegious behavior towards the host almost never stood alone but were rather part of a long list of heterodox practices of which the New Christians of Muslim origin were accused. For example, when the Inquisition of Cuenca charged the morisco Luis Hernández with apostasy in 1569, it accused him of maintaining that he believed in Muhammad; that there was no Trinity; that the Virgin was not a virgin; and that the body of Christ was not present in the consecrated host-which he was reported to have called "just a little bread (panete) or a little bit of paper."47 In 1601-1602, the morisca María de Talavera was tried by the Inquisition of Toledo for removing the consecrated wafer from her mouth and placing it inside a glove. ${ }^{48}$ María claimed that she took the host out of her mouth because she had an urge to vomit but that she later ate it. The inquisitors accepted her version, and she received a relatively minor punishment, penitential in nature. All the same, the case, which echoes the Eucharistic tale of the sinful woman and the Muslim alfaquí discussed above, demonstrates the particular attention of inquisitors and early modern Spanish society to morisco contact with the Eucharist.

Some of the sacrilegious attitudes of which moriscos were accused reflected not only unbelief, but veritable mockery and ridicule. For instance, the Inquisition of Cuenca accused the morisco Gaspar Belbís in 1537 of having bought consecrated hosts stolen by a Christian thief from a local church. Belbís was then said to show complete and utter disrespect to the Eucharist: the inquisitors accused him of stringing together the hosts with a thread and hanging them with a nail in a "dishonest place," most probably a latrine-the same crime of which the so-called judaizers of Córdoba were accused (as mentioned above). ${ }^{49}$ How can we account for these tacit yet evident resemblances between inquisitorial accusations against moriscos and conversos? Such similarities could be explained as the outcome of a common rejection of key Catholic doctrines among members of two religious groups who had been forced to convert to Christianity. Both Jewish and Muslim polemical literature against Christianity included strong criticism of the Eucharist, which

\footnotetext{
${ }^{47}$ Archivo Diocesano de Cuenca, Inquisición, 246: 3298, fol. 51v.

${ }^{48}$ Julio Sierra, Procesos en la inquisición de Toledo (1575-1610): Manuscrito de Halle (Madrid, 2005), 503 n. 970.

${ }^{49} \mathrm{ADC}$, Inq. 133: 1695A, fol. 66r.
} 
may have informed some of the attitudes reported in inquisitorial trials. ${ }^{50}$ But this resemblance also could be explained as a consequence of the fact that both groups were persecuted by the same institution, namely, the Inquisition. Whether inquisitors drew on methods used against conversos in their activities against moriscos is a question that goes beyond the scope of this present essay. But it is clear in both cases that as part of its working method the Inquisition actively looked for rejection of Catholic rituals as an indication of heresy and apostasy. In the Spain of the Inquisition, attitudes toward the Eucharist marked religious difference: they indicated that New Christians, whether they were of Jewish or Muslim origin, were in fact apostates and heretics.

\section{From Profanation to Expulsion: Precedents and Links}

While both conversos and moriscos were targets of inquisitorial persecution, it was only the latter who were expelled from Spain after their conversion to Christianity. The decision to expel baptized Christians was in many ways an unprecedented course of action and called for a significant campaign of justification. This campaign was undertaken through diplomatic efforts as well as by means of a proliferation of printed propaganda. These texts, published just after the beginning of the expulsion and seeking to legitimize it, accused the moriscos time and again of sacrilegious behavior towards the Eucharist. Significantly, these expulsion apologies also drew direct connections between Jewish and morisco host profanation. ${ }^{51}$

Among the apologists of the expulsion of the moriscos the Dominican Friar Jaime Bleda takes a prominent place. He was an inquisitor and a protégé of the all-powerful archbishop of Valencia, Juan de Ribera. In 1585, Ribera appointed Bleda as an acolyte in the town of Corbera, where a significant population of moriscos lived. As Bleda would later write, it was during mass in Corbera when he realized the extent to which the conversion of the moriscos was a complete and utter failure. Entering the church while the priest raised the host, Bleda knelt down near the door. From his concealed position, he saw how those "infidels," instead of venerating the host and the chalice, "scorned and mocked the Eucharist." The women pinched the toddlers so that they would cry, and there was not a single morisco who did not

\footnotetext{
${ }^{50}$ See Rubin, Gentile Tales, 93-103; Hava Lazarus-Yafeh, "Some Neglected Aspects of Medieval Muslim Polemics against Christianity," Harvard Theological Review 89 (1996): 61-84, at 78-79; Cardaillac, Moriscos y cristianos, 292-95.

${ }^{51}$ On the expulsion apologists, see Mercedes García-Arenal and Gerard Wiegers, eds., The Expulsion of the Moriscos from Spain: A Mediterranean Diaspora, trans. Consuelo LópezMorillas and Martin Beagles (Leiden, 2014).
} 
wiggle his lips or interfere with the mass, all in "manifest derision, insult, and outrage to the holy sacrament." Shocked by this heretical behavior, Bleda returned to Valencia and asked to be removed from office, but was denied his request. It was at this moment, he writes, that he decided to find the way to "liberate the holy sacrament from those injurious sacrileges." 52

Bleda spent the following decades in total commitment to the anti-morisco cause, seeking to convince secular and ecclesiastical authorities of the urgency of the matter. During this time, Bleda published several works, among them a book dedicated to the Eucharist. This book describes various Eucharistic miracles, which prove, as usual in such narratives, that Christ was truly present in the Eucharist and that the host possessed or at least channeled divine powers. Among these tales appears the famous case of alleged Jewish host profanation known as the "Billettes affair," mentioned above, which Bleda dates to 1306, the year in which Philip IV the Fair expelled the Jews from France. ${ }^{53}$ This was not a simple mistake. It is quite plausible that Bleda here followed the Franciscan Alonso de Espina, who claimed in his virulent polemical work, The Fortress of the Faith (composed between 1459-1561), that he had heard in Medina del Campo from Cluniac monks that the Jews were expelled from France because they profaned a host. ${ }^{54}$

Together with this and other anti-Jewish Eucharistic tales, Bleda's book included narratives in which Muslims and moriscos figured as enemies of the host. Most took place in the context of military struggles, yet among them we can also find the story about the sinful woman and the Muslim sage, which Bleda took directly from Jaume Roig. ${ }^{55}$ Once again, Eucharistic tales of Jewish profaners appeared side by side with those of Muslim profaners. Bleda, however, not only placed narratives of Jewish and Muslim host desecration side by side but also made inferences from one to the other. This anti-morisco apologist emphasized one important aspect of the Paris 1290 host profanation libel, namely that it led to punishment of the entire Jewish community, not only of the accused Jewish profaner. For Bleda, this offered a model to emulate in the case of the moriscos. Just as Philip IV of France expelled the Jews after the "Billettes affair," Bleda argued, the moriscos should be expelled from "all of Spain" on account of the "injuries" they had committed against the holy sacrament. ${ }^{56}$

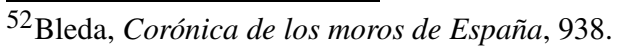

${ }^{53}$ Jaime Bleda, Libro de la cofradia de la Minerva: En el qual se escriuen mas de dozientos y cinquenta milagros del Santissimo Sacramento del Altar (Valencia, 1600), 92-99 (milagro 20). Bleda published a shorter version of the same treatise in 1592.

${ }^{54}$ Alonso de Espina, Fortalitium Fidei (Lyon, 1487), II. IX, fol. 167.

${ }^{55}$ For Roig's tale, see Bleda, Libro de la cofradia de la Minerva, 181-83 (milagro 95). For other Eucharistic tales including Muslims, see 65-70 (milagro 7), 76-77 (milagro 11), 333-35 (milagro 223).

${ }^{56}$ Bleda, Corónica, 918.
} 
While Bleda's book of Eucharistic miracles reflects aspects of his general anti-morisco campaign, it was another work, titled Defense of the Faith on the Issue of the Neophytes or Moriscos of the Kingdom of Valencia and the Whole of Spain, that proved to be his most influential work. This work circulated among secular and ecclesiastical notables in manuscript versions in the late 1590 s and early 1600 s, before it was finally published in Latin in 1610. The Defense of the Faith, which contained a list of ninety-one proofs demonstrating that the moriscos were heretics and apostates, including their sacrilegious behavior during mass, was Bleda's main weapon in his campaign against the moriscos. ${ }^{57}$ References to Jews abound throughout this anti-morisco text, and they are not exclusively related to the Eucharist. For instance, Bleda argues that the moriscos are apostates because they mock the cross. Christians, therefore, should intervene to defend the faith. Bleda gives two examples of efforts to do so. In Lisbon in 1506, Old Christians killed over two thousand New Christians of Jewish origin after one of them mocked popular veneration of a miraculous crucifix. Bleda marshals this event, well known to Jewish historians thanks to the seminal study of Yosef Hayim Yerushalmi, as another precedent for collective action against moriscos. ${ }^{58}$

Bleda's second example cites a story told by Alonso de Espina about the expulsion of the Jews from England. The English king (unnamed by Espina and Bleda) forcibly converted all the Jews of his realm. After observing that the natural disasters that the Jews' infidelity had brought upon his kingdom did not then cease, the king decided to test the sincerity of these New Christians. He ordered the construction of two pavilions in a field near the port. In the first he placed the Torah and in the second the cross. He then told the newly converted to choose between them voluntarily. After the converts turned to the Torah, the king, saddened by this, ordered that their throats be slit and their bodies thrown into the sea. Bleda concludes: "There is no doubt that if a similar test was made with those New Christians [i.e., the moriscos], their perfidy would be proven since they deny the cross and the Crucified and embrace the beast Muhammad." 59 As in various other places throughout the vitriolic pages of the Defense of the Faith, Bleda draws on precedents from

\footnotetext{
${ }^{57}$ For the "proof" that moriscos were hostile to the Eucharist, see Jaime Bleda, Defensio fidei in causa neophytorum, sive Morischorum Regno Valentiae totiusque Hispaniae (Valencia, 1610), 39. For the ways in which Bleda used his prepublished book to convince dignitaries, see Manuel Ruiz Lagos, Contra Moriscos: El sumario Bleda (Huelva, 2009).

${ }^{58}$ See Yosef Hayim Yerushalmi, The Lisbon Massacre of 1506 and the Royal Image in the "Shebet Yehudah" (Cincinnati, 1976).

${ }^{59}$ Bleda, Defensio fidei, 44-45: "profecto istud esset efficacius argumentum omnibus, que ego hic scribo, ad probandam eorum perfidiam: interpide enim, \& insolenter, non Christi Crucem, nec ipsum Dominum crucifixum, sed bestiam illam, Mahometum inquam, amplecterentur."
} 
anti-Jewish literature to make his case that the moriscos were all apostates and should be expelled.

Given the fundamental influence of the Defense of the Faith on other expulsion apologies, it is hardly surprising to find in the latter similar allegations and arguments. A case in point is the anti-morisco book titled Justified Expulsion of the Spanish Moriscos composed by the Aragonese friar Jerónimo Aznar and his nephew, the licenciado Pedro Aznar y Cardona (who signed the work). ${ }^{60}$ The general thrust of this malicious work is an attempt to substantiate Bleda's arguments with details that give a sense of historicitydetails that are sometimes missing from other expulsion apologies. In a long and very detailed discussion of moriscos' animosity towards the host, the authors of the Justified Expulsion described moriscos not only as secretly ridiculing the Eucharist, but also as brazenly desecrating it. In one incident, for example, a morisco throws a cloth dirtied with feces on the chalice as the priest is raising the host. ${ }^{61}$ But it is not only the detail included in this work that is of interest. As a matter of fact, the treatment of morisco sacrilege in this work goes beyond formally echoing the accusations of host profanation leveled against Jews and conversos or seeing anti-Jewish policies as model for the morisco problem. The book takes a step further and establishes a direct link between the two groups. If the moriscos accepted the truth of Catholic sacraments, argue the authors of the book,

They would not deny what they ought to admit, nor would they accept things according to their capricious whim, as do the obstinate Jews, [who] deny the real and true presence of the most sacred body of Christ in the holy sacrament of the altar under the accidents of bread and wine. And the moriscos expelled from Spain have always followed those harshly incredulous Jews. ${ }^{62}$

This is not an isolated statement in the Justified Expulsion. While arguing that the moriscos were apostates and rejected and ridiculed the Eucharist, the book offers a long discussion which, quite astonishingly, focuses on the Jews. This not always systematic argument draws on classical Christian polemic

\footnotetext{
${ }^{60}$ Pedro Aznar Cardona, Expulsion justificada de los Moriscos españoles, y suma de las excellencias Christianas de nuestro Rey Don Felipe el Catholico Tercero (Huesca, 1612). On the book and its authors, see Julio Caro Baroja, "Los Moriscos aragoneses según un autor de comienzos del siglo XVII," in idem, Razas, pueblos y linajes (Madrid, 1957), 81-98.

${ }^{61}$ Aznar Cardona, Expulsion justificada, fol. $63 \mathrm{v}$.

${ }^{62}$ Aznar Cardona, Expulsion justificada, fol. 62r: "y assi fundandose en la verdad, no negarian, lo que deuen conceder, ni solo aceptarian lo que les dita su antojo boltario, como los Iudios obstinados, niegan la presencia real y verdadera, del cuerpo sacratissimo de Christo en el Santo Sacramento del altar, debaxo de los acidentes de pan y de vino: y a estos Iudios duramente incredulos, han seguido siempre en este error heretico, los Moriscos expellidos de España."
} 
against Judaism by comparing Scriptural traditions and pointing to the "falsifications of the Talmudists." Towards the end, however, it surveys Eucharistic miracles-most prominently, that of the alleged Jewish host profanation in Paris, 1290, but also some that involve Muslims-with which it proves the truth of the Eucharist. At the end of this rather inconsistent argument, the final conclusion of the Justified Explusion is nevertheless unequivocal: "the moriscos followed the error that Muhammad took from the Jews." 63

\section{Intersecting Histories}

The evidence presented above complicates the exceptionalist historiographical narrative that sees accusations of host profanation only within the framework of increasingly deteriorating Christian-Jewish relations. At the very least, it shows that in premodern Iberia, Christians considered both Jews and Muslims as potential enemies of the Eucharist. It might be tempting to see this argument along the lines of R. I. Moore's thesis about the "persecuting society." 64 According to Moore, the rise of centralizing state power in medieval Europe was tied to the emergence of scapegoating discourses that legitimized violence against minorities, be they Jews, heretics, women, homosexuals, or lepers (Muslims are not mentioned in the work). Moore's thesis may therefore provide a general model with which we can understand the accusations of host profanation leveled against Iberia's "Others." This muchdiscussed thesis, however, cannot replace the close analysis of the particular realities of late medieval and early modern Iberia, which also included cohabitation and exchange between religious groups. Nor can it equip us with a lens powerful enough to look at the specifities of anti-Judaism and antiIslam. It equally does not account for the reciprocal ties between accusations of Jewish/converso and Muslim/morisco host profanation.

In that final respect, not only should the exceptionalist historiographical narrative of Jewish host profanation be revised but also any neat division between Jews as "theological enemies" and Muslims as "political enemies"

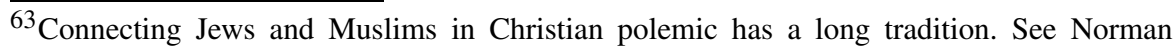
Daniel, Islam and the West: The Making of an Image (Oxford, 2009), 105-6, and the references there in n. 21; Sidney H. Griffith, "Jews and Muslims in Christian Syriac and Arabic Texts of the Ninth Century," Jewish History 3, no. 1 (1988): 65-94; John C. Lamoreaux, "Early Eastern Christian Responses to Islam" in Medieval Christian Perceptions of Islam: A Book of Essays, ed. John V. Tolan (New York, 1996), 3-31, at 14.

${ }^{64}$ Robert I. Moore, The Formation of a Persecuting Society: Authority and Deviance in Western Europe, 950-1250 (Malden, MA, 2007).
} 
must be nuanced. ${ }^{65}$ Instead, the complex relations between the two in Christian imagination and policy should be explored further. True, there can be no doubt that Jews and Judaism hold a unique, perhaps incomparable place in Christian thought. ${ }^{66}$ Yet in some specific contexts, Christians thought about their sacred order through two, interrelated "objects" rather than one. This was frequently the case in premodern Iberia, yet there may be comparable cases elsewhere. I do not want to belabor the argument. There are crucial differences between the histories of Jews and Muslims in Iberia, as well as between the histories of the conversos and the moriscos. But these histories are not necessarily two parallel paths that never intersect. At times they overlap and inform one another. Christian polemical literature, inquisitorial inquiries, law codes, and Eucharistic tales and art might draw direct connections between these groups, lump them together, and even regard them as interchangeable. As a matter of fact, in some of the religious plays celebrating the miracle of the Sacred Forms of Alcalá with which this essay opened, it was not moriscos who committed the sacrilege, but Jews. ${ }^{67}$

Acknowledgments The author would like to thank Miriam Bodian, Yanay Israeli, and Cloe Cavero de Carondelet for their valuable comments and suggestions.

Open Access This article is licensed under a Creative Commons Attribution 4.0 International License, which permits use, sharing, adaptation, distribution and reproduction in any medium or format, as long as you give appropriate credit to the original author(s) and the source, provide a link to the Creative Commons licence, and indicate if changes were made. The images or other third party material in this article are included in the article's Creative Commons licence, unless indicated otherwise in a credit line to the material. If material is not included in the article's Creative Commons licence and your intended use is not permitted by statutory regulation or exceeds the permitted use, you will need to obtain permission directly from the copyright holder. To view a copy of this licence, visit http://creativecommons.org/ licenses/by/4.0/.

Publisher's Note Springer Nature remains neutral with regard to jurisdictional claims in published maps and institutional affiliations.

\footnotetext{
${ }^{65}$ See, for example, Dwayne E. Carpenter, "Minorities in Medieval Spain: The Legal Status of Jews and Muslims in the Siete Partidas," Romance Quarterly 33 (1986): 275-87, at 276. The division is a subject of an insightful critique by Gil Anidjar, The Jew, the Arab: A History of the Enemy (Stanford, 2003).

${ }^{66}$ The literature on the subject is vast. For an ambitious recent analysis, see David Nirenberg, Anti-Judaism: The Western Tradition (New York, 2013).

${ }^{67}$ Juan Carlos Garrot Zambrana, "El Auto de las formas de Alcalá y el antijudaísmo de los años 1630," eHumanista 3 (2015): 246-66.
} 